\title{
MENGEMBANGKAN SUMBER DAYA INSANI DALAM BISNIS: KONSTRUKS PEMIKIRAN TEOLOGIS
}

\author{
Muhammad Djakfar \\ Fakultas Ekonomi Universitas Islam Negeri Maulana Malik Ibrahim \\ Jalan Gajayana 50 Malang \\ E-mail:dj4kfar.2010@gmail.com/ HP.08155524601
}

\begin{abstract}
Business industry progress of the country not always runs same way with ethic rule and law, this reality is disadvantage. One of sources is the personal quality of religious back ground. In spite of that this writing to give solution which how to develope human resources developmant bocome spiritual personality in thinking and acting. The sources are taken from library text, media on line, electronic and paper media were critized in Islamic law or maqashid al-Syariah. Based on analized that recommended of developing the future human resources development can be hold by Islamic college, School as like honesty canteen, family and society. By this approach is hoped building the complete HRD in spitituality, knowledge, morality, professionality and good Islamic relationship. Therefore they, human economicmaterilistic, do economic activity as The Islamic law, theology approach, which bring their life to be good, humanity, ethic value and justice. We do hope.
\end{abstract}

Key word: sumber daya insani, bisnis, pemikiran teologis

Mengembangkan sumber daya insani (SDI) (QS.Al-Insan, 76:1-2) merupakan masalah krusial dalam berbagai aspek kehidupan ini, tanpa kecuali dalam aktivitas bisnis. Masalah bisnis merupakan aktivitas kunci dalam kemajuan ekonomi sebuah negara yang kemudian dikenal dengan istilah sektor riil. Yakni sebuah aktivitas yang benar-benar nyata untuk memenuhi hajat hidup masyarakat dengan jalan mengelola segala sumber daya yang tersedia. Dalam kaitan dengan masalah produksi, SDI merupakan salah satu faktor yang harus ada, selain tanah (land), modal (capital), dan organisasi (management-corporate). Kendati demikian, nampaknya di masa mendatang, patut diduga, seirama dengan perkembangan zaman yang ditandai perkembangan ilmu pengetashuan dan teknologi, masalah faktor-faktor ini kian berkembang, antara lain yang berkaitan dengan masalah informasi dan teknologi yang memadai. Tanpa ketercukupan informasi yang didukung ketersediaan teknologi yang mumpuni rasanya akan sulit sebuah corporate mampu berkembang di era globalisasi saat ini. Terlebih lagi untuk meraih tingkat keunggulan yang 
kompetitif (competitive exellence) maupun komparatif (comparative exellence) di dalam kancah global.

Namun demikian perlu disadari bahwasanya dari sekian faktor produksi itu bagaimanapun keberadaan "manusia" merupakan faktor kunci (key factor) yang mempunyai nilai strategis. Artinya, keberadaan manusia (SDI) dalam setiap aktivitas bisnis hampir tidak, atau bahkan tidak mungkin tergantikan oleh faktor-faktor yang lain. Sejalan dengan ini sangatlah logis sekali apabila Tuhan menjadikan manusia sebagai khalifah di muka bumi (istikhlaf) dengan tugas untuk memakmurkannya (isti'mar). Nampaknya Tuhan Maha Tahu, bahwasanya yang mampu mengemban kekhalifahan dan memenej kehidupan alam raya ini hanyalah manusia dengan seperangkat potensi yang dianugerahkannya. Dengan kata lain, dalam konsep teologis, yang mampu mengembangkan usaha dalam upaya untuk memenuhi segala kebutuhan hidup manusia hanyalah sejenis makhluk hidup yang bernama"manusia."

Hanya saja ketersediaan SDI bagaimanapun harus diikuti dengan kemampuan skill yang harus dimiliki. Untuk menjadikan perusahaan yang unggul misalnya, tidaklah cukup hanya diukur dengan seberapa banyak jumlah SDI yang tersedia secara kuantitas (quantity), namun juga harus diikuti dengan kualitas (quality) yang harus disandang oleh mereka untuk menduduki pos jabatan (job) sesuai kompetensi masing-masing. Tanpa kualitas SDI, niscaya efisiensi dan efektifitas manajemen perusahaan tidak akan pernah terwujud yang pada akhirnya akan berujung pada matinya sebuah perusahaan di masa mendatang.

Perlu diakui di era modern ini tidaklah sedikit perusahaan yang merekrut SDI yang high skill untuk menjadikan perusahaan yang sedang dibangun berada di garis terdepan dalam memenangkan persaingan yang semakin ketat. Bahkan tidak sedikit pula mereka sengaja meng-up grade SDI melalui program in service training dengan harapan untuk meningkatkan produktifitas yang berkelanjutan agar eksistensi perusahaan tetap terjaga dan diakui. Perusahaan modern niscaya menyadari bahwasanya untuk mempertaruhkan eksistennya secara suistainable kehadiran SDI yang berkualitas merupakan sebuah keniscayaan. Karena itu untuk terus meningkatkan kualitas SDI mereka mengaplikasikan manajemen sumber daya manusia yang banyak diterapkan dalam perusahaan modern di berbagai negara.

Hanya saja perlu diakui pula bahwa membangun SDI yang berkualitas tidaklah cukup hanya bermodalkan kemampuan akademik semata yang pada 
dasarnya hanyalah mengandalkan kemampuan potensi pikir manusia yang dapat dikatakan lepas samasekali dari ikatan transenden. Atau, steril dari bingkai ajaran spiritualitas yang tersambung dengan Sang Maha Pencipta dan Maha Pemberi kekayaan. Sebab itu sangatlah wajar apabila soft skill maupun hard skill yang dimiliki SDI perusahaan saat ini banyak diwarnai oleh hasil perenungan atau pencarian para saintis sekuler yang secara tegas memisahkan antara urusan perusahaan dengan nilai-nilai agama. Sebagaimana yang dapat kita pahami dari para pemikir ekonomi yang berbasis aliran kapitalistisme maupun sosialisme.

SDI yang sudah terpola oleh mainstream pemikiran sekularistik itu, baik mereka yang menduduki posisi puncak dalam sebuah perusahaan (pelaku) maupun bagi mereka dalam statusnya sebagai pelaksana, hanyut dalam sebuah pola pikir dan paradigma "dari modal, demi modal, untuk modal." Atau, "dari profit, demi profit, untuk profit." Sebagai konsekuensinya, dalam melaksanakan usaha mereka selalu terjebak pada motivasi bagaimana cara mendapatkan keuntungan sebanyakbanyaknya agar perusahaan terus berkembang dan besar. Paradigma semacam ini tolok ukur kepuasannya hanyalah pada materi (bendawi) semata, sehingga dalam realitasnya demi meraih keuntungan yang sebesar-besarnya, mereka tidak jarang mengorbankan nilai-nilai kemanusiaan, melangkahi norma-norma moral dan etika, serta menabrak hukum yang berlaku. Dan secara kasat mata tidak jarang pula para pelaku usaha menghalalkan segala macam cara yang merugikan baik kompetitor maupun konsumen yang sejatinya perlu dilindungi hak-haknya. Dengan kata lain, dalam realitas patut diduga, bahwa nampaknya kualitas SDI sebagai pelaku akan dapat mewarnai baik tidaknya aktivitas dunia usaha di mana-mana.

Oleh karena itu bertolak dari keprihatinan kualitas SDI itulah diskursus ini ingin menawarkan sebuah solusi agar pengembangan SDI itu sedianya juga harus berbasiskan ajaran teologi (Qardhawi,1995; Mannan,1995; Djakfar,2010; Naqvi,1994). Berpegang teguh dan kembali pada ajaran agama (back to religion and spirituality value) yang menghasilkan sebuah konstruks teologis bahwa dalam melakukan bisnis hendaknya para pelakunya bertolak dari sebuah paradigma "dari Tuhan, karena Tuhan, untuk Tuhan." (Djakfar, 2010; Qardhawi, 1995; Mannan, 1995).

\section{Mengeksplorasi Potensi dan Ranah Pengembangan}

Dalam al-Qur'an banyak potensi diri yang diberikan oleh Tuhan kepada manusia agar dapat memenuhi kebutuhan hidupnya secara sempurna dengan 
menggali dan memanfaatkan sumber daya alam yang disiapkan untuk mereka. Potensi diri dimaksud meliputi akal (al-'aql) (QS,An-Nahl,16:44), hati (al-qalb) (QS.AlAn'am,6:110), nafsu (al-nafs) (QS.,Yusuf,12:53), jiwa (al-ruh) (QS.As-Sajdah, 32:9), dan jasmani (al-jism) (QS.At-Tin, 95:4).

Semua potensi tersebut merupakan anugerah Tuhan yang diberikan oleh Tuhan yang dengan sendirinya pasti ada maksud dan tujuan di balik penciptaannya. Dengan kata lain, aneka ragam potensi tersebut tidaklah akan sia-sia sehingga dengan demikian perlu dieksplorasi secara maksimal untuk kemudian difungsikan secara maksimal pula. Untuk dapat mengembangkan SDI secara maksimal, maka hendaknya potensi-potensi tersebut perlu disinergikan antara yang satu dengan yang lain sesuai fungsinya masing-masing. Hal ini dimaksudkan agar setiap potensi itu tidaklah berjalan sendiri-sendiri, namun terjadi kolaborasi, yang satu menguatkan yang lain, sejalan dengan ruh semangat ajaran Islam itu sendiri yang mengajarkan untuk segala kebaikan agar selalu dilakukan secara bersama-sama (berjemaah). Inilah sinergitas yang menjadi karakteristik ajaran Islam yang hanif.

Dalam kaitan dengan dunia usaha (bisnis) dengan bertolak dari berbagai potensi yang dimiliki manusia, maka ranah pengembangan SDI dapat ditujukan pada aspek kedalaman spiritual, keagungan akhlak, keluasan ilmu pengetahuan, kematangan profesional (Pedoman Pendidikan, 2011), dan kekuatan silaturahim. Kedalaman spiritual, perlu dikembangkan karena manusia dianugerahi hati (al-qalb) sebagai pusat bersemayamnya iman. Selain mempunyai jiwa yang dapat menghubungkan diri manusia secara individu dengan Rabb-nya.

Demikian pula pengembangan keagungan akhlak karena manusia memiliki hati untuk menerima petunjuk agama, selain memiliki akal untuk membedakan sesuatu yang baik daripada yang buruk yang semuanya untuk mengendalikan nafsu ammarah menuju nafsu mutmainnah. Selain itu ilmu pengetahuan perlu menjadi ranah pengembangan karena manusia memiliki akal untuk melakukan perenungan dan pemikiran tentang ayat-ayat qawliyyah (wahyu) maupun qawniyyah (alam semesta) agar menghasilkan sesuatu yang maslahah bagi kehidupan manusia.

Adapun dalam kaitan dengan kematangan profesional agar hendaknya SDI yang kita kembangkan dalam mengoptimalkan potensi dirinya benar-benar mampu memenej usaha secara profesional (itqan) sesuai ajaran Islam (QS. An-Naml, 27:88; lihat pula HR. Baihaqi dari Siti 'Aisyah, dalam Shahih al-Jami' ash-Shaghir). Sedangkan yang dimaksud dengan ranah pengembangan silaturahim (networking) 
diharapkan agar SDI dalam kapasitasnya sebagai makhluk sosial perlu banyak melakukan hubungan antarmanusia selaku konsumen (stakeholder) dalam dunia usaha. Tanpa dukungan modal sosial melalui networking, mustahil kiranya sebuah usaha akan sukses dilakukan.

\section{Berbagai Kasus yang Berkembang}

Pada bagian ini akan dikemukakan beberapa contoh kasus yang berkembang di dunia usaha, terutama di Indonesia, yang telah banyak meresahkan masyarakat dalam kapasitasnya sebagai konsumen (stakeholder). Dalam kenyataan, kasus-kasus itu dapat dikatakan sudah sedemikian merata di berbagai macam aktivitas bisnis dari tingkat hulu sampai hilir. Sehingga dengan demikian pelakunya adalah pebisnis kelas atas maupun bawah dengan berbagai modus operandi yang dilakukan untuk melakukan menyimpangan. Di antara contoh kasus yang dimaksud dapat dikemukakan sebagai-berikut: Pertama, terjadinya praktik penjualan bakso bercampur babi (dioplos dengan daging sapi) (Republika, 3 Januari 2013). Bahkan jauh sebelumnya pernah terjadi, tepatnya diawal tahun 2009, empat produk dendeng di pasaran mengandung DNA babi (Republika, 2 Juni 2009).

Kedua, beredarnya sepatu merek Kickers yang berbahan kulit babi tapi berlogo halal. Padahal Direktur LPPOM MUI, Lukmanul Hakim, mengaku tidak pernah merekomendasikan logo halal sehingga ia meminta produk tersebut ditarik di pasaran (Republika, 2 Januari 2013, Surya, 26 Desember 2012).

Ketiga, dalam dunia telekomunikasi misalnya, beberapa waktu yang lalu telah terjadi kartelisasi penentuan harga satuan pesan pendek (SMS) yang tidak sesuai dengan harga dasar (menurut Badan Regulasi Telekomunikasi Indonesia, Rp.75 per SMS) yang dilakukan beberapa perusahaan (operator) di Indonesia. Mereka adalah PT Telkomsel, PT Excelcomindo Pratama Tbk (XL), PT Telkom, PT Bakrie Telekom Tbk, PT Mobile-8 Telecom Tbk, dan PT Smart Telecom. Keenam perusahaan ini telah memberlakukan tarif antara Rp.250 sampai Rp.350, sehingga dengan demikian menurut catatan KPPU, kerugian konsumen, pertengahan tahun 2008 pada saat itu , sudah mencapai Rp.2,8 triliun (Jawa Pos, 23 Juni 2008).

Keempat, beredarnya alat kosmetika yang tidak aman dikonsumsi. Bahkan di akhir tahun 2012 terdeteksi sejumlah 48 alat kosmetika yang sejatinya tidak aman bagi kesehatan pemakainya (Jawa Pos, 29 Desember 2012). Artinya, jika alat kecantikan tersebut seringkali dikonsumsi, bukanlah tidak mungkin dalam jangka 
panjang akan mengganggu kesehatan penggunanya. Demikian pula dengan berbagai kasus yang terjadi di dunia perbankan, antara lain sering terjadi pembobolan dana nasabah seperti yang dilakukan oleh Melinda Dee di Citibank (Okezone, 26 Desember 2011).

Terus merebaknya perdagangan barang haram seperti narkoba. Rasanya telah menjadi rahasia umum bahwa Indonesia nampaknya merupakan salah satu negara di dunia yang dijadikan sararan untuk penjualan barang terlarang ini, sehingga hampir tiap hari media cetak maupun elektronik memuat berita mengenai kasus ini. Sebab itu sangatlah wajar apabila saat ini pemerintah Indonesia mencanangkannya sebagai "negara darurat narkoba." Secara psikologis, statmen ini menyimpan makna, bahwasanya masalah narkoba telah masuk dalam status "awas", sangat membahayakan dan perlu diwaspadai oleh karena dampaknya yang sedemikian besar bagi seluruh kehidupan bangsa.

Selain itu, menurut catatan Kementerian Perdagangan dalam tahun 2012 yang lalu, setidaknya ada 3.000 produk yang tidak layak edar di pasaran (Kompas, 17 Januari 2013, 18). Kendati sebagian besar produk tersebut adalah produk impor, justru mengapa pedagang (importir) Indonesia tidak bersikap waspada agar konsumen di negeri ini dapat terlindungi. Sekalipun konsumen dihimbau agar cerdas memilih sebuah produk, apakah semua mereka mampu membedakan antara produk berkualitas atau justru sebaliknya. Inilah sejatinya yang menjadi tuntutan kepada produsen atau penjual agar masyarakat tidak banyak dirugikan.

Kesemua kasus tersebut merupakan akibat dari kualitas perilaku SDI perusahaan yang kering dari nilai-nilai spiritualitas. Mereka adalah penghamba materi yang hanya merasa bertanggung jawab kepada perusahaan semata, tidak juga kepada Tuhan, selaku Pemberi harta kekayaan yang diamanahkan. Mereka seakanakan telah menjadikan materi sebagai berhala yang perlu dicari, setelah itu jika perlu disembah atau dimuliakan. Inilah sejatinya karakter paham yang mengedepankan nilai-nilai materialistik yang berparadigmakan "dari modal, demi modal, dan untuk modal." sebagaimana telah dikemukakan sebelum ini.

Paradigma semacam ini tidak jarang seringkali banyak dipraktikkan dalam bisnis yang merugi yang pada umumnya mempunyai karakter antara lain investasi modal yang jelek, dilakukan melalui keputusan yang tidak sehat, dan seringkali menimbulkan perilaku yang jahat (Ahmad, 2001). Sebagai kebalikan dari karakteristik bisnis yang menguntungkan yang berjalan di atas koridor ajaran wahyu. 
Karakter bentuk bisnis yang terakhir ini pada umumnya modalnya diinvestasikan dengan cara yang sebaik-baiknya atau ke dalam bisnis yang baik-baik semata karena senantiasa berharap ridha dari Allah SWT. Selain juga dilakukan melalui keputusan yang sehat dengan perilaku bisnis yang benar dan terpuji.

Karakter bentuk bisnis yang kedua tersebut dengan sendirinya merupakan refleksi dari paradigma teologis sebagaimana telah disinggung sebelum ini yakni "dari Tuhan, karena Tuhan, untuk Tuhan." Dengan demikian dari kedua karakter bentuk bisnis itu dapat diapahami bahwa bisnis yang merugi adalah lebih banyak disebabkan karena orientasinya hanya untuk mengumpulkan materi (modal-materi) semata. Di dalamnya seakan-akan tidak ada sama sekali nilai agama (spiritualitas) yang pada akhirnya praktik bisnis semacam ini terjerembab ke dalam dunia profan yang merugikan.

Sebaliknya bisnis yang berparadigmakan ketuhanan, akan sarat dengan nilainilai spiritualitas (transenden) dengan keyakinan bahwa bagaimanapun bisnis tidak dapat lepas dari ajaran ketuhanan (teologis) sehingga dalam pelaksanaannya harus senantiasa mengacu kepada segala ketentuan Tuhan sebagaimana yang diajarkan melalui firman-Nya kepada Muhammad Rasulullah saw. (Qardhawi, 1995). Kendati demikian bentuk bisnis yang berorientasikan paradigma teologis selalu berupaya untuk menyeimbangkan antara kebutuhan dunia dan akhirat, antara kebutuhan ragawi dan rohani, antara keutuhan diri (corporate) dan kebutuhan orang lain (konsumen-stakeholder), dan lain sebagainya.

Karena itu dalam praktiknya, bisnis yang berorientasi nilai-nilai transenden (uluhiyyah) itu berkecenderungan tidak akan melakukan praktik kotor (keji-jahat) yang berpotensi merugikan masyarakat. Pelakunya berkeyakinan bahwa aktivitas bisnis merupakan ibadah, sedangkan harta kekayaan yang diperoleh bukanlah tujuan, namun hanyalah sebatas sebagai instrumen untuk meraih falah di akhirat. Ajaran inilah sejatinya yang harus menginternalisasi ke dalam diri SDI pelaku bisnis melalui berbagai instrumen yang ada agar kemudian dapat menjadi bagian dari perilaku bisnis yang digelutinya.

\section{METODE}

Dengan bertolak dari berbagai penyimpangan sebagaimana dikemukakan di atas (sebagian kasus yang terjadi), maka tujuan utama penulisan wacana (discourse) ini adalah untuk menawarkan sebuah solusi pemahaman, sekaligus penyadaran agar 
kasus-kasus serupa tidak terulang kembali. Paling tidak, dapat mengeleminir, sebagai jalan keluar (way out) dengan cara mencermati kunci pokok masalahnya, antara lain yang berkaitan dengan kualitas SDI pelakunya.

Dan dengan semakin banyaknya kasus penyimpangan bisnis yang berlaku, mengindikasikan bahwa sistem ekonomi saat ini yang dianut oleh para pelaku bisnis ternyata telah banyak merugikan dan merusak sendi-sendi kehidupan masyarakat luas. Hanya demi kepentingan bisnis, mereka agaknya kurang begitu peduli lagi pada kepentingan konsumen sebagaimana tercermin dalam ajaran maqasid al-syariah yang diajarkan dalam Islam (Chapra, 2001:124). Sebab itu di tengah kerapuhan sistem kapitalis yang telah sedemikian mengakar sebagai maindset pemikiran ekonomi global saat ini, sudah saatnya mereka digugah untuk mempertimbangkan pula sistem ekonomi Rabbaniyyah (Teologis) yang transenden yang menekankan keseimbangan dunyawiyyah dan ukhrawiyyah (Qardhawi, 1995)). Sistem Rabbaniyyah mengajarkan, ada kehidupan akhirat setelah kehidupan di alam fana ini agar manusia mempertanggung jawabkan semua perbuatannya selama hidup di dunia, tanpa kecuali dalam aktivitas bisnis.

Dengan demikian agar para pelaku bisnis, khususnya di kalangan pelaku bisnis Muslim Indonesia, menyadari bahwa bagaimanapun aktivitas bisnis yang dilakukan tidak lepas dari ikatan teologis yang bersumber pokok dari etos ajaran alQur'an dan Sunnah Rasulullah saw. Islam diturunkan bukanlah tanpa makna dan tujuan, namun di balik itu mengandung maksud-maksud tertentu sebagaimana terpatri dalam ajaran maqasid al-syariah (Chapra, 2001:124) yang pada intinya ingin melindungi manusia pemeluknya dalam berbagai aspek kehidupan yang meliputi agama (al-din), jiwa (al-nafs), akal (al-'aql), keturunan (al-nasl), dan harta (al-mal) mereka. Oleh karena itu berbagai bentuk kasus atau penyimpangan bisnis yang dapat ditelusuri melalui data kepustakaan (dokumenter) akan dikritisi (dianalisis) melalui ajaran maqasid al-syariah ini.

Inilah sejatinya yang perlu dikonstruks dan diinternalisasikan secara intens dan sistemik melalui berbagai saluran institusi ke dalam diri pelaku maupun calon pelaku bisnis. Sehingga dengan demikian wacana ini dapat dikategorikan sebagai hasil penelitian pustaka (library research) untuk memecah kasus-kasus yang berkembang dewasa ini yang antara lain disebabkan oleh kualitas sumber daya insaninya yang terjauh dari nilai-nilai teologis. Konstruks pemikiran kritis itu disajikan secara deskriptif dengan menggunakan alur epistemologis yang 
menekankan pada aspek proses sebagaimana salah satu alur pikir yang dikenal dalam filsafat ilmu.

\section{HASIL DAN PEMBAHASAN}

Berdasarkan hasil identifikasi beberapa kasus menyimpang dalam bisnis yang berpotensi merugikan masyarakat selaku konsumen telah terpapar pada bagian kasus yang berkembang. Yakni kasus tentang makanan, pakaian (dalam hal ini sepatu), kosmetika, keuangan dan perdagangan narkoba. Data seluruh kasus tersebut diperoleh dengan jalan penelusuran pustaka, dalam hal ini, beberapa media massa yang selama ini banyak dikonsumsi oleh masyarakat, seperti internet, Republika, Jawa Pos, Surya dan Kompas. Kecuali yang berkaitan dengan masalah perdagangan narkoba, kiranya telah sedemikian banyak sumber yang menjelaskan kasusnya, baik media cetak maupun elektronik. Sebab itu khusus untuk kasus terakhir ini sengaja tidak disebutkan sumbernya karena sudah menjadi pengetahuan umum masyarakat luas.

Aneka kasus tersebut dianalisis dengan menggunakan perspektif ajaran maqasid al-syariah (Chapra, 2001:124) yang pada dasarnya menegaskan bahwa kehadiran syariat Islam di tengah kehidupan manusia mengandung maksud dan tujuan-tujuan tertentu sebagaimana telah dijelaskan sebelum ini. Oleh karena itu setiap praktik bisnis yang tidak sejalan dengan ajaran maqasid al-syariah dengan sendirinya masuk ke dalam praktik penyimpangan yang layak dikritisi. Untuk selanjutnya ke depan perlu dicarikan jalan keluarnya dengan jalan mengembangkan SDI pelakunya yang berwawasan ajaran teologis dalam Islam.

\section{Analisis Kasus}

Dalam kaitan dengan kasus yang pertama, dalam hal ini adalah bakso yamg berbahan daging oplosan antara daging sapi dengan daging babi pada dasarnya sebagai akibat karena langkanya persediaan daging sapi di pasar sehingga secara hukum ekonomi apabila persediaan (supply) terbatas, sementara permintaan (demand) tetap, atau bahkan kian meningkat, maka akan terjadi melambungnya harga. Atau akan terjadi distorsi harga yang kadangkala tidak wajar. Namun demikian kondisi semacam ini sudah menjadi hukum pasar yang bersifat alamiah, atau universal karena bisa terjadi kapan pun dan di manapun saja. 
Akan tetapi menurut kacamata ekonomi Islam, kelangkaan seperti di atas tidaklah dapat dijadikan alasan untuk melakukan kecurangan yang berpotensi akan merugikan hak-hak konsumen. Dalam hal ini produsen (penjual) harus mampu menyeimbangkan (balance-tawazun) antara kepentingan corporate dengan kepentingan konsumen, agar tidak terjadi eksploitasi yang menabrak ketentuan etika maupun hukum yang berlaku (Pratley, 1997). Bukankah perbuatan semacam itu merupakan praktik kebohongan publik yang patut mendapat hukuman yang setimpal, tidak hanya di dunia, bahkan juga kelak di hadapan Tuhan yang Maha Tahu dan Maha Adil.

Dilihat dari perspektif ajaran maqasid al-syariah, sudah barang tentu bisnis bakso semacam itu telah mencederai akidah (al-din) para konsumen Muslim yang karena ketidaktahuannya mereka mengkonsumsinya. Dalam ajaran Islam yang bersumber dari al-Qur'an dan Sunnah kiranya sudah pasti bahwa setiap Muslim dilarang keras mengomsumsi barang haram tersebut. Sebab itu jika sekiranya para penjual bakso bersikap terbuka yang menyatakan bahwa bakso produksinya berbahan daging babi, niscaya masyarakat akan mampu memilih sesuai keyakinannya. Atau, bagi komunitas Muslim, mereka akan berupaya menyelamatkan diri dari mengkonsumsi sebuah makanan yang berasal dari bahan yang tegas terlarang secara agama.

Justru karena itu letak kesalahan mendasar praktik penjualan bakso berbahan oplosan daging babi seperti di atas, mereka telah melakukan penipuan dengan mengorbankan akidah konsumen yang sejatinya perlu dihormati dan dilindungi oleh produsen. Sungguh merupakan perbuatan yang sangat tidak terpuji dari kacamata apa pun karena telah mengorbankan hak orang lain, demi kepentingan sesaat dalam hal ini bisnis.

Demikian pula untuk kasus kedua yakni penjualan sepatu bermerek Kickers yang sempat beredar di Indonesia. Kendati sepatu ini sebagian bahan bakunya menggunakan kulit babi, namun dari berita yang sempat beredar menggunakan label halal. Ini berarti telah terjadi sebuah kontradiksi antara pelabelan dengan bahan baku yang digunakan, sehingga dapat dikatakan pihak produsen atau pun penyalur di Indonesia telah melakukan kebohongan publik sebagaimana yang dilakukan oleh pedagang bakso di atas. Dampak teologisnya kepada para pemakai komunitas Muslim di Indonesia adalah pencederaan keimanan (akidah) yang sejatinya tidak perlu tetrjadi. 
Selanjutnya dalam kaitan dengan kasus ketiga, yakni praktik kartelisasi yang dilakukan oleh beberapa perusahaan telekomunikasi di Indonesia. Mereka sepakat menaikkan harga satuan SMS dari harga dasar yang telah ditentukan, sehingga dengan demikian telah merugikan para konsumen Indonesia yang sedemikian potensial. Mereka sepakat melakukan praktik tidak terpuji hanya demi kepentingan bisnis semata dengan mengorbankan kepentingan konsumen secara material.

Memang karena keawaman para konsumen itu sendiri, sehingga mereka tidak pernah melakukan klaim apa pun berkaitan dengan masalah harga. Apakah satuan harga yang telah dibayar kepada masing-masing perusahaan itu telah patut atau layak sesuai ketentuan yang berlaku? Atau justru sebaliknya? Sedangkan pihak perusahaan secara sepihak memanfaatkan keawaman itu untuk meraup keuntungan yang sebesar-besarnya agar masing-masing perusahaan bisa tumbuh berkembang sesuai yang diharapkan. Namun demikian, di balik perbuatannya itu ternyata mereka juga telah melakukan penipuan dan kebohongan publik yang melanggar nilai-nilai kebajikan yang berlaku. Sama halnya dengan kedua kasus yang lain, berarti mereka telah menyalahi nilai-nilai etika secara universal, tanpa kecuali telah menyalahi hukum yang berlaku di Indonesia.

Nampaknya, para perusahaan seluler itu tidak menyadari bahwa pengguna telepon genggam dewasa ini tidaklah sama status sosialnya, yang secara tidak langsung akan menggambarkan kemampuan ekonomi mereka masing-masing. Di era teknologi informasi saat ini penggunaan telepon, sebagai alat komunikasi, telah dianggap sebagai kebutuhan mendasar (dharuri) yang harus dipenuhi. Karena itu jika terjadi permainan harga yang unfairness jelas merupakan tindakan yang menyalahi hak dasar konsumen guna memenuhi salah satu kebutuhannya.

Bahkan dilihat dari ajaran maqasid al-syariah, perbuatan perusahaan seluler jelas tidak lagi melindungi aspek kekayaan konsumen (al-mal) karena mereka harus membayar setiap satuan harga berkomunikasinya melebihi harga yang tidak sepatutnya. Atau, mereka telah melakukan upaya pemiskinan terselubung dan sistemik para konsumen pengguna seluler, terutama dari kalangan masyarakat kelas bawah. Inilah sejatinya letak kesalahan mereka dilihat dari aspek ajaran teologi, bahwa dalam melakukan usaha hendaknya para pelaku selalu bertumpu pada perintah Tuhan selaku Pemilik mutlak, antara lain perlu bersikap manusiawi (humanity) dan mengedepankan keadilan (akhlaqi-'adalah). 
Kendati beda kasus dengan modus operandi yang berbeda pula, nampaknya kasus ketiga ini mempunyai titik persamaan dengan kasus kelima yakni yang berkaitan dengan masalah perbankan. Yaitu sebuah kasus yang terjadi di tubuh perbankan swasta Amerika dengan aktor utamanya Melinda Dee. Selaku orang dalam yang mempunyai posisi terhormat, selayaknya Melinda melindungi dana nasabah agar aman dari pembobolan. Namun ternyata dana simpanan nasabah Citibank senilai Rp.40 miliar dibobol oleh Inong Melinda alias Melinda Dee selama kurang lebih tiga tahun (Okezone-Senin, 26 Desember 2011, 12:04 wib). Jaksa penuntut umum mendakwa Melinda melakukan penggelapan dan pencucian uang dalam kurun waktu 22 Januari 2007 hingga 7 Februari 2011 melalui 117 transaksi, di mana 64 transaksi di antaranya dalam bentuk pecahan rupiah senilai Rp.27,36 miliar dan 53 transaksi senilai 2,08 juta dolar AS (Okezone-Senin, 26 Desember 2011, 12:04 wib).

Selanjutnya dalam kaitan dengan kasus keempat, yakni masalah kosmetika (sebanyak 48 merek) yang ditengarai tidak aman dikonsumsi. Sebagaimana kita ketahui bahwa alat kecantikan di era modern ini merupakan sebuah kebutuhan, terutama bagi kaum Hawa. Seringkali penggunaan alat kosmetika dikaitkan dengan harga diri dan status sosial seseorang. Dalam arti, semakin mahal dan bermerek kosmetik yang digunakan niscaya akan menaikkan gengsi si pemakainya.

Suatu hal yang perlu diwaspadai karena seringkali kurang menguntungkan bagi kesehatan masyarakat, bahwasanya masyarakat Indonesia terlalu menomorsatukan barang impor, kendati belum tentu aman bagi pemakainya. Tentu saja hal ini terkait dengan masalah budaya komsumsi masyarakat Indonesia yang dikenal sedemikian konsumtif (Kompas, 17 Januari 2013). Kedatangan kosmetik impor, tentu saja tidak lepas bagaimana perilaku importir Indonesia yang dihadapkan pada pilihan. Yakni melindungi konsumen atau bisnis. Atau melindungi keduanya. Apabila pilihannya melindungi keduanya, niscaya importir akan waspada, apakah produk itu aman bagi konsumen, selain juga berhitung dalam masalah keuntungan (profit).

Sebaliknya apabila importir kurang waspada atau secara sengaja mendatangkan produk yang tidak aman bagi kesehatan penggunanya, maka sama halnya mereka telah melanggar ajaran maqasid al-syariah, dalam hal ini tidak melindungi jiwa manusia (al-nafs). Katakan saja dengan menggunakan salah satu produk impor, penggunanya lambat atau cepat akan menderita penyakit kanker 
kulit yang dapat mengacam jiwanya. Inilah kesalahan fatal yang perlu disadari oleh pada pelaku bisnis agar tetap berpegang teguh pada ketentuan Tuhan sebagaimana yang diajarkan dalam Islam. Karena bagaimana pun jiwa seseorang harus kita lindungi keselamatannya. Tidak mencari keuntungan demi kepentingan perusahaan semata.

Terakhir kasus keenam yang berkaitan dengan perdagangan narkoba yang nampaknya tidak mudah untuk diberantas, karena mempunyai jaringan yang sedemikian rapi dan sulit dideteksi. Kehadiran Badan Narkotika Nasional (BNN) di negeri kita tujuan utamanya adalah untuk menanggulagi mengguritanya bisnis dan penggunaan barang haram ini yang telah banyak makan korban. Narkoba adalah sejenis zat atau obat yang membuat kecanduan penikmatnya dan dalam waktu tertentu akan dapat mengganggu kesehatan yang bersangkutan. Kendati zat ini tidak dikenal dalam al-Qur'an dan Sunnah, namun karakternya mengandung persamaan dengan khamar yang sudah jelas haram hukumnya, karena dapat memabukkan sehingga mengganggu fungsi akal penggunanya (lihat QS. AlBaqarah,2:219; Al-Ma'idah,5:90). Sebab itu hukum penggunaan narkoba dapat dianalogikan kepada hukum khamar yakni sama-sama haram dikonsumsi, karena illat yang sama, yakni memabukkan, merusak akal (bandingkan dengan QS. AnNisa', 4:43), dan merusak kesehatan serta moral ayang dapat mengganggu ketertiban masyarakat.

Dalam kenyataan tidak sedikit dampak negatif sebagai akibat penggunaan zat ini baik bagi penikmatnya maupun dampak terhadap lingkungan secara luas. Betapa banyak tabrakan di jalan raya karena pengemudinya mabuk dan hilang konsentrasi karena baru mengkonsumsi narkoba. Akan sangat tragis sekali apabila sebagai penggunanya adalah anak-anak kita yang masih usia muda karena akan merenggut masa depan mereka di masa datang. Sehingga dengan demikian jika sekiranya dalam sebuah negara para generasi mudanya telah terlibat pemakaian narkoba, niscaya akan sirnalah harapan kejayaan keluarga, dan lebih jauh harapan masa depan negara.

Karena itu siapa pun pelaku perdagangan zat berbahaya ini dalam perspektif maqasid al-syariah tak ubahnya telah ikut menghancurkan generasi pelanjut dalam sebuah keluarga (al-nasl) yang mungkin dapat disebut dengan loss generation. Bahkan lebih jauh telah memutus rantai kepemimpinan masa depan sebuah negara karena generasi mudanya tidak lagi berkualitas sebagai pemimpin baik dalam aspek mental, 
moral, daya pikir dan lain sebagainya. Inilah di antara alasan justru mengapa aktivitas perdagangan narkoba dilarang baik oleh syariat maupun negara manapun di dunia. Dan pelakunya patut mendapat hukuman yang seberat-beratnya karena perbuatan dosanya yang merugikan banyak kalangan.

\section{Model dan Institusi Pengembangan: Perspektif Epistemologis}

Selanjutnya pada bagian ini akan didiskripsikan bagaimana model-model pengembangan SDI, khususnya di negeri mayoritas Muslim seperti Indonesia. Dalam kenyataan, kiranya cukup banyak institusi yang dapat dijadikan wadah pengembangan secara maksimal. Asalkan saja benar-benar dikelola secara profesional dengan pengelola yang mempunyai sense of responsibility yang tinggi dan profesional pula. Tanpa sistem manajemen yang mumpuni dengan dukungan subjek pengelola yang kapabel dan mempunyai komitmen yang tinggi serta profesional, niscaya usaha pengembangan itu akan sia-sia.

Dalam arti, upaya pengembangan yang dilakukan tidak akan mempunyai makna signifikan atau kontribusi yang nyata dalam upaya mengembangkan SDI di negeri ini. Kegagalan atau kekurangberhasilan dalam pengembangan SDI dapat diprediksi akan berdampak pada kegagalan pembangunan dunia bisnis yang unggul dalam menghadapi globalisasi yang semakin kompetitif dan komparatif. Sebab itu, inilah signifikansinya mengfungsikan beragam institusi yang telah ada di tengah masyarakat kita dengan menggunakan pola yang relevan yang memungkinkan untuk dilakukan. Dengan tujuan untuk mengembangkan SDI dalam bingkai teologis dan menjadikan aktivitas bisnis sebagai bagian dari ibadah kepada Tuhan yang wajib dilakukan. Atau, dengan kata lain, membentuk SDI yang mampu melaksanakan bisnis sebagai refleksi dari rasa keimanan dan realisasi ibadah hanya kepada-Nya.

Sejatinya banyak model yang dapat digali di Indonesia dengan mempertimbangkan berbagai institusi yang ada, misalnya model pendidikan formal (persekolahan), model pesantren, model keluarga, dan model uji coba dalam bentuk kantin kejujuran. Hanya saja model terakhir ini saat ini sudah tidak kedengaran lagi gaungnya. Model pertama, yakni persekolahan (formal). Saat ini di tengah semakin sulitnya menembus kerja di sektor formal, nampaknya pemerintah mulai menggalakkan program pendidikan kewirausahaan, terutama di perguruan tinggi (lihat Djakfar, 2007:13). Dengan tujuan, apa pun disiplin ilmu yang dimiliki 
diharapkan para sarjana kita mampu mandiri, tidak bergantung kepada orang lain (Swasono, 2005:216). Sebagai sebuah lembaga pendidikan, perguruan tinggi mempunyai peran strategis dalam mengembangkan SDI yang berkualitas dan profesional saat ini dan akan datang untuk membangun ekonomi bangsa (Djakfar, 2010:316). Selain mencetak pemikir-pemikir (akademisi-peneliti) yang handal sebagai tugas utama sebuah lembaga pendidikan.

Peran strategis itu akan semakin jelas untuk beberapa perguruan tinggi yang di dalamnya mempunyai fakultas ekonomi, karena di dalam fakultas inilah mahasiswa akan mendapat teori dan praktik masalah bisnis agar mereka setelah lulus mampu menciptakan lapangan kerja sendiri. Karena itu akhir-akhir ini adanya pengembangan fakultas ekonomi menjadi fakultas ekonomi dan bisnis, seperti Universitas Brawijaya misalnya, diharapkan para lulusannya tidak hanya menguasai teori-teori ekonomi, namun juga menguasai seluk beluk masalah bisnis yang sangat dibutuhkan membangun kemandirian bangsa.

Fakultas ekonomi sebagai wadah candradimuka pemikir dan pelaku ekonomi dan bisnis itu dewasa ini tidak saja di bawah naungan perguruan tinggi umum, namun juga di lingkungan perguruan tinggi agama Islam seperti Universitas Islam Negeri dengan kurikulum yang memuat nilai-nilai spiritualitas (Islam) (Djakfar, 2010:316). Inilah sebenarnya peran perguruan tinggi dalam mengembangkan SDI dalam dunia bisnis yang inklusif sesuai tuntunan ajaran syariat.

Selanjutnya model yang kedua pondok pesantren. Di tengah masyarakat, terutama Muslim, peran ulama (dengan beberapa sebutan: ajengan-kyai-keyae-buya) sangatlah strategis sekali, baik dalam persoalan agama maupun masalah-masalah kontemporer kemasyarakatan (lihat Djakfar,2010:284; Dhofir,1982:55; Arifin,1993:14; Keddie, 1978:2; Shihab, 1993:375; Horikoshi, 1987:148-188). Tanpa kecuali komunitas Muslim Indonesia. Namun demikian yang tidak kalah signifikannya adalah program aksi yang mereka lakukan sebagai perwujudan dari ajaran muamalah ke dalam dunia nyata dalam bentuk aktivitas bisnis dengan berbagai ragamnya (Djakfar, 2010:294).

Tidaklah sedikit di antara ulama yang telah melakukan eksperimentasi bisnis secara riil, terutama bagi mereka yang memangku pesantren. Katakan saja pengasuh Pondok Pesantren Assirojiyyah Sampang Madura (Djakfar, 2007), Pondok Modern Gontor Ponorogo, Pondok Pesantren An-Nur Bululawang Malang, Pondok 
Pesantren Sidogiri Pasuruan (Bakhri, 2004). Keempat pesantren tersebut dalam mengembangkan usaha telah banyak mempekerjakan para santrinya sebagai pengelola, terutama bagi mereka yang senior dan sudah tamat dari pondok. Misalnya, pesantren Assirojiyah mempekerjakan sekitar 50 santri untuk menangani beberapa unit usaha yang meliputi: kopontren (berdiri 1982), toko Navaka (berdiri 1997), radio Salsabila (berdiri 1999), percetakan (berdiri 1991), kantin (berdiri 1982), dan qirad (berdiri 1995).

Demikian pula pengalaman pesantren Sidogiri secara total juga mempekerjakan para santri (dan alumni) untuk terlibat dalam mengoperasikan unit usahanya yang berupa koperasi pondok pesantren (Kopontren), koperasi baitul mal wa tamwil maslahah mursalah lil ummah (BMT MMU), dan koperasi usaha usaha gabungan terpadu (UGT). Unit usaha ini sekarang berkembang pesat tidak saja di daerah Pasuruan, bahkan juga di luar Pasuruan, antara di pulau Madura. Sumbangan konkret pesantren yang telah mengembangkan kewirausahaan tersebut dalam mengembangkan SDI pelaku bisnis yang berbasis teologis sudah jelas tidak diragukan lagi. Bukanlah santri yang dipekerjakan itu adalah mereka yang telah mengenyam pendidikan agama di pesantren yang tidak saja mengajarkan masalah ibadah, namun juga masalah muamalah dan akhlak dalam kehidupan.

Dengan demikian kontribusi riil dunia pesantren, mereka ielah mampu membekali para santrinya tidak saja secara teori (akademik), namun sekaligus juga praktik dalam dunia nyata tentang ajaran muamalah yang pernah diterimanya. Lebih jauh dapat dikatakan, pesantren secara tidak langsung telah mampu membangun kultur bisnis dalam sebuah atmosfer dunia usaha keseharian di lingkungan kampus pesantren yang mencerminkan bagaimana sejatinya implementasi ajaran muamalah dalam aktivitas bisnis yang disyariatkan dalam Islam.

Demikian pula keberadaan dunia usaha yang ada di lingkungan keluarga (Muslim) kiranya tidak kalah krusialnya dalam mengembangkan SDI calon pelaku bisnis yang handal dan inklusif sesuai ajaran syariah. Bagi pebisnis Muslim yang shaleh dalam upaya mencetak kader penerus usaha keluarga seyogianya menanamkan nilai-nilai bisnis Islami yang terikat dengan nilai-nilai teologis. Dengan demikian apabila mereka kelak telah masuk ke dalam dunia bisnis yang sebenarnya akan berperilaku terpuji dalam mengendalikan bisnisnya, sebagaimana perilaklu bapaknya yang shaleh. Hanya saja dalam hal ini sang bapak tidak cukup berkhotbah 
dengan kata-kata, tetapi harus membuktikan pula dengan uswah bisnis yang terpuji di tengah keluarga dekatnya.

Akhirnya, institusi lain yang dapat dijadikan sebagai salah satu upaya mencetak kader SDI dalam bidang bisnis yaitu keberadaan kantin kejujuran yang beberapa waktu yang lalu pernah diuji cobakan. Seyogianya program ini terus berlanjut untuk membentuk lingkungan bagi anak sejak usaha dini. Inilah sejatinya laboratorium kejujuran yang justru perlu dibangun di sekolah-sekolah, antara lain dengan jalan membuka kantin secara swalayan, di mana anak, dalam hal ini siswa mengambil sendiri barang yang dibeli. Selanjutnya, ia membayar dan mengambil uang pengembalian sendiri sebagai taruhan apakah seorang anak berlaku jujur atau sebaliknya.

Jika pada masa awal belum berhasil, maka secara rutin perlu dilakukan evaluasi. Namun demikian di antara kiat yang perlu diperhatikan hendaknya kantin diposisikan sebagai milik bersama, misalnya milik koperasi sekolah agar ada rasa tanggung jawab bersama. Wujud rasa milik bersama akan termotivasi adanya pengawasan bersama pula dari seluruh keluarga sekolah. Di sisi lain para guru di kelas perlu selalu menanamkan nilai-nilai kejujuran dan menjadikan kejujuran sebagai perilaku keseharian warga dalam segala hal. Apabila nilai kejujuran telah menginternalisasi dan menjadi bagian dari kepribadian warga sekolah, maka diharapkan kelak nilai kejujuran itu akan berdampak pula pada perilaku bisnis yang baik. Maksudnya, di sini diharapkan akan terjadi transferability nilai kebajikan ke dalam segala ranah kehidupan. Demikian seterusnya.

\section{KESIMPULAN DAN SARAN}

\section{Kesimpulan}

Bertolak dari paparan di atas dapat disimpulkan bahwa upaya pengembangan SDI merupakan sebuah keniscayaan karena semakin bervariasinya kasus yang sudah benar-benar memprihatinkan. Ke depan kasus-kasus tersebut tidak akan pernah surut. Bahkan kecenderungan akan terus bertambah. Sebab itu mengantisipasinya perlu adanya suatu gerakan yang komprehensif, integratif, tidak sektoralistik. Artinya, perlu adanya sinergitas antarpotensi yang ada. Kunci utama maraknya penyimpangan dalam dunia bisnis tidaklah lepas karena faktor SDI pelakunya yang sudah terdistorsi paradigma kapitalistik yang pada intinya hanya mengejar kekayaan semata. Mereka seakan teralienasi dari ikatan spiritual yang 
menegaskan bahwa aktivitas bisnis apa pun merupakan sebuah amanah sehingga dalam operasionalnya tidak boleh lepas dari segala ketentuan-Nya. Mindset semacam inilah yang perlu diinternalisasikan ke dalam pikiran mereka di atas kesadaran sebuah paradigma bahwa melakukan bisnis pada dasarnya harus termotivasi karena Allah SWT dan untuk Allah SWT. Karena kekayaan yang dikelola dalam bisnis pada hakikatnya adalah amanah dan milik Allah semata.

\section{Saran}

Proses internalisasi itu antara lain dapat melalui jalur kultural maupun struktural yang menyimpan banyak potensi di dalamnya dengan harapan agar SDI yang dikembangkan akan mempunyai lima kekuatan, yakni kedalaman spiritual (hatinya selalu dekat kepada Tuhan), keagungan akhlak (mampu mengendalikan nafsu untuk menghargai nilai-nilai kebajikan), keluasan ilmu pengetahuan (akalnya berfungsi secara optimal), kematangan profesional (raganya sehat dan kuat dalam melaksanakan aktivitas dengan sempurna), dan kekuatan silaturahim (potensi dirinya dimanfaatkan untuk membangun jaringan antarmanusia). Dan dengan lima kekuatan inilah akhirnya diharapkan SDI yang kita kembangkan akan merasa mempunyai ikatan teologis yang kuat, sehingga dalam melaksanakan bisnis mereka akan peduli pada faktor kemanusiaan (humanity), memperhatikan etika (akhlaqi), bersikap adil ('adalah), tranparansi (fairness) dan lain sebagainya. 


\section{DAFTAR RUJUKAN}

\section{Al-Qur'an al-Karim}

Ahmad, Mustaq. 2001. Etika Bisnis dalam Islam, ter. Samson Rahman. Jakarta: Pustaka Al-Kautsar

Arifin, Imron. 1993. Kepemimpinan Kyai: Kasus Pondok Pesantren Tebuireng. Malang: Kalimasada Press

Bakhri, Mokh. Syaiful. 2004. Kebangkitan Ekonomi Syariah di Pesantren: Belajar dari Pengalaman Sidogiri. Pasuruan: Cipta Pustaka Utama

Chapra, M. Umer. 2001. The Future of Economics: An Islamic Perspective Landscape Baru Perekonomian Masa Depan, ter. Amdiar Amir, dkk. Jakarta: Shari'ah Economics and Banking Institute (SEBI)

Dhofir, Zamakhsyari. 1982. Tradisi Pesantren: Studi tentang Pandangan Hidup Kyai. Jakarta: LP3ES

Djakfar, Muhammad. 2007. Menumuhkan Spirit Kewirausahaan Untuk Membangun Indonesia Yang Bermartabat. Malang: UIN-Malang Press

Djakfar, Muhammad "Agama dan Etos Bisnis Elit Pesantren Salafiyah: Studi Kasus Pondok Pesantren Assirojiyah Sampang Madura," dalam JABM, Jurnal Akuntansi-Bisnis \& Manajemen, Volume 14 Nomor 3, Desember 2007

Djakfar, Muhammad. 2010. Teologi Ekonomi Membumikan Titah Langit di Ranah Bisnis. Malang: UIN-Maliki Press

"Empat Produk Dendeng di Pasaran Mengandung DNA Babi," dalam Republika, 2 Juni 2009

Horikhosi, Hiroko. 1987. Kyai dan Perubahan Sosial. Jakarta: P3M

Keddie, Nikki R. (ed). 1978. Scholar, Saints, and Sufis. California: University of California Press

Kickers Tarik Semua Sepatu Kulit Babi Polda Tetap Mengusut, Surya, 26 Desember 2012

"Konsumen Perlu Cerdas, Produk Bermutu Rendah Makin Membanjiri Pasar," Kompas, edisi 17 Januari 2013

Mannan, M. Abdul. 1995. Teori dan Praktik Ekonomi Islam, ter. M. Nastangin. Yogyakarta: PT. Dana Bhakti Wakaf

Mansurnoor, Iik Arifin. 1990. Islam in an Indonesian World: Ulama of Madura. Yogyakarta: Gajah Mada University Press 
Naqvi, Syed Nawab Haider. 1994. Islam, Economics, and Society. London and New York: Kegan Paul International

Program Pascasarjana Universitas Islam Negeri Maulana Malik Ibrahim. 2011. Pedoman Pendidikan Pasca Sarjana UIN Maliki. Malang: UIN Press

Pratley, Peter. 1997. The Essence of Business Ethics, Etika Bisnis, ter. Gunawan Prasetio. Yogyakarta: Penerbit Andi

Qardhawi, Yusuf. 1415H. Dawr al-Qiyam al-Akhlaq fi Iqtishad al-Islamiy. Qahirah: Maktabah Wahbah

Qardhawi, Yusuf, 1995. Peran Nilai dan Moral dalam Perekonomian Islam, ter. K.H. Didin Hafidhuddin, dkk. Jakarta: Robbani Press

Shihab, M. Quraish. 1993. Membumikan al-Qur'an Fungsi dan Peran Wahyu dalam Kehidupan Masyarakat. Bandung: Penerbit Mizan

Suman, Agus. "Menyibak Topeng Kartel Seluler," dalam Jawa Pos, 23 Juni 2008

Swasono, Sri-Edi. Menuju Entrepreneurial University, Bahan Seminar Sehari Dalam Rangka Dies Natalis Universitas Brawijaya ke-42, Januari 2005

Jawa Pos, 29 Desember 2012

"Kasus Melinda Dee yang Sensasional," dalam Okezone- Senin 26 Dersember 2011

Republika, 2 Januari 2013

Republika, 3 Januari 2013 